\title{
Transient protection by peripheral benzodiazepine receptors during the early events of ultraviolet light-induced apoptosis
}

\author{
P-E Stoebner ${ }^{1}$, P Carayon ${ }^{2}$, P Casellas ${ }^{2}$, M Portier ${ }^{2}$, \\ T Lavabre-Bertrand $^{3}$, P Cuq ${ }^{4}$, J-P Cano ${ }^{4}$, J Meynadier ${ }^{1}$ \\ and $L$ Meunier ${ }^{\star}, 1$ \\ 1 Department of Dermatology-Allergology-Photobiology, Hôpital St-Eloi, CHU \\ Montpellier, France \\ 2 Immuno-Oncology Department, Sanofi-Synthelabo Recherche, Montpellier, \\ France \\ 3 Department of cytology and cytogenetics, CHU Nîmes, France \\ ${ }^{4}$ Laboratory of Drug Toxicology, Montpellier, France \\ * Corresponding author: L Meunier, Department of Dermatology, Hôpital \\ Caremeau, av. du Professeur Debré, CHU Nîmes, 30900 France. Tel: 0466 \\ 683171; Fax: 0466 683791; E-mail: laurent-meunier@chu-nimes.fr
}

Received 28.8.00; revised 2.2.01; accepted 8.2.01

Edited by $\mathrm{G}$ Salvesen

\begin{abstract}
The peripheral benzodiazepine receptor (PBR) is a mitochondrial protein involved in the formation of mitochondrial permeability transition (PT) pores which play a critical role during the early events of apoptosis. PBRs are located in many tissues and are strongly expressed in the superficial layers of human epidermis. PBRs play a protective role against free radical damage and PBR ligands modulate apoptosis. To investigate the role of PBR during the early events of ultraviolet (UV)-mediated apoptosis we compared the effects of UVB on PBR-transfected Jurkat cells and their wild type counterparts devoid of any PBR expression. Results indicate that early after UVB exposure (up to $4 \mathrm{~h}$ ), PBR-transfected cells were more resistant to apoptosis and exhibited a delayed mitochondrial transmembrane potential drop, a diminished superoxide anions production, and a reduced caspase-3 activation. Taken together these findings suggest that PBR may regulate early death signals leading to UV induced apoptosis. Cell Death and Differentiation (2001) 8, 747-753.
\end{abstract}

Keywords: apoptosis; mitochondria; peripheral benzodiazepine receptor; ultraviolet

Abbreviations: A, annexin V; ANT, adenine nucleotide translocator; $\mathrm{DiOC}_{6}, 3,3^{\prime}$-dihexyloxacarbocyanine iodide; $\Delta \Psi \mathrm{m}$, mitochondrial transmembrane potential; HE, dihydroethidine; MPT, mitochondrial permeability transition; PBR, peripheral benzodiazepine receptor; PBR-J, peripheral benzodiazepine receptortransfected Jurkat cells; PT, permeability transition; PTPC, PT pore complex; PCD, programmed cell death; PI, Propidium lodide; ROS, reactive oxygen species; UVB, ultraviolet B; VDAC, voltagedependent anion channel; WT-J, wild type Jurkat cells

\section{Introduction}

The peripheral benzodiazepine receptor (PBR) is a $18 \mathrm{kDa}$ protein that is expressed on mitochondrial outer membranes, essentially distributed in peripheral tissues, and that is distinct from central benzodiazepine receptors. ${ }^{1,2}$ Endogenous ligands for PBRs include protoporphyrin IX and a newly described cytoplasmic protein, PRAX-1, that specifically interacts with these receptors., ${ }^{3,4}$ PBRs are involved in steroidogenesis, heme biosynthesis, immune and stress responses, cell growth, differentiation and mitochondrial respiratory control. ${ }^{5}$ Recent data also suggest that PBR is structurally and functionally related to the Rhodobacter sphaeroides tryptophan-rich sensory protein (TspO). Complementation experiments demonstrated that PBR was able to substitute for TspO taking part of a signal transduction pathway that regulates gene expression in response to oxygen. ${ }^{6,7}$ Within the mitochondrial membrane, PBR is closely associated with voltage-dependent anion channel (VDAC) and adenine nucleotide translocator (ANT) proteins which are involved in the formation of mitochondrial permeability transition (PT) pores. ${ }^{8}$ These multiprotein complexes play a critical role in apoptosis as opening PT pores and reduction of mitochondrial potential are the early irreversible steps of the programmed cell death (PCD) process. $^{9-13}$ Interestingly, PBR has been shown to preserve the mitochondria of hematopoietic cell lines from damage induced by oxygen radicals ${ }^{14}$ and PBR ligands were found to modulate apoptosis. ${ }^{15,16}$ In human skin, as PBR expression is strongly upregulated in the superficial differentiated layers of the epidermis, those receptors are thought to play a protective role against free radical damage and apoptosis generated by ultraviolet (UV) light. ${ }^{17}$ In order to investigate the role of PBR during the early events of UVmediated apoptosis, we analyzed the effects of UVB exposure on PBR-transfected Jurkat cells (PBR-J) ${ }^{14}$ compared to their wild-type counterparts (WT-J) devoid of any PBR expression.

\section{Results}

We choose the Jurkat cell lines because: (i) WT-J cells are naturally devoid of any PBR expression; (ii) and are non adherent cultured cells that do not require chemical or mechanical treatments which by themselves may modify the phosphatidylserine expression. Results of all the experiments were similar between clones 12-2-F8, 31-1-B10 and 12-2-D2 and there were no difference between Jurkat cell lines transformed with vector controls ( $\mathrm{pHb}$ Neo APR1-J) and wild type Jurkat cells (WT-J). All the experiments were repeated thrice. $\chi^{2}$ and Wilcoxon tests were used for statistical analysis. 


\section{Analysis of early apoptosis induced by UVB treatment}

Cells were labeled with Annexin-FITC (A) and Propidium lodide (PI). Apoptosis was first analyzed by flow cytometric analysis with increasing UVB doses $\left(10-500 \mathrm{mj} / \mathrm{cm}^{2}\right)$ at $1 \mathrm{~h}$. A representative experiment is shown on Figure 1. Per cent of apoptotic but still viable cells $\left(\mathrm{A}^{+} \mathrm{PI}^{-}\right)$was reduced in PBR-J cells compared to WT-J cells with a dose-dependent effect. An optimal difference of apoptotic response between the two cell lines was observed with a $100 \mathrm{~mJ} / \mathrm{cm}^{2}$ dose. Therefore we decided to study the kinetic of apoptosis at 1, 4, 12 and $24 \mathrm{~h}$ by using this irradiance. A representative experiment is shown on Figure 2a. Per cent of non viable $\mathrm{Pl}^{+}\left(\mathrm{Pl}^{+} \mathrm{A}^{+}\right)$cells increased after an acute UVB exposure in both cell lines. However, up to $4 \mathrm{~h}$ after UV treatment, the per cent of $\mathrm{A}^{+} \mathrm{PI}^{-}$ cells was significantly reduced in PBR-J cells compared to WT-J cells ( $13 \%$ vs $44 \%$ at $1 \mathrm{~h} ; 50 \%$ vs $75 \%$ at $4 \mathrm{~h}$ ). At $12 \mathrm{~h}$, most of cells have undergone apoptosis in both cell lines, the $\mathrm{PI}^{+}$subset being still reduced in PBR-transfected cells $(46 \%$ vs $60 \%$ ). Such differences were confirmed from multiple experiments and there was no statistically significant difference between each tested PBR-transfected clones (Figure $2 b, c)$. Furthermore, results were similar between wild type (WT-J) and cells transfected with an empty vector $(\mathrm{pHb}$ Neo APR1-J). At $1 \mathrm{~h}$ significant changes in early apoptosis were evidenced: WT-J cells exhibited a higher percentage of $\mathrm{A}^{+} \mathrm{PI}^{-}$cells than that of PBR cells (clone 12-2-F8: $34.1 \pm 6.17 \%$ versus $11 \pm 1.7 \%, P=0.001$ ). At $4 \mathrm{~h}$, such difference was also shown with a mean per cent of $\mathrm{A}^{+} \mathrm{PI}^{-}$ cells of $51.9 \pm 2.66 \%$ in PBR-J cells (clone 12-2-F8) compared to that of $70.6 \pm 5.25 \%$ in WT-J cells $(P=0.001)$ (Figure $2 \mathrm{~b}$ ). No significant loss of viability was observed after 1 and $4 \mathrm{~h}$ in wild type and PBR-transfected cell lines. Twelve hours after UVB exposure, the per cent of non viable $\mathrm{A}^{+} \mathrm{PI}^{+}$ cells in WT-J was higher (clone 12-2-F8: $63.3 \pm 3.5 \%$ ) than that in PBR-J cells $(47.0 \pm 2.65 \%)(P=0.001)$ while the per cent of $\mathrm{A}^{+} \mathrm{PI}^{-}$PBR-J cells $(36.7 \pm 5.7 \%)$ was higher than that of WT-J cells ( $26 \pm 6 \%$ ) (Figure $2 \mathrm{c}$ ). At $24 \mathrm{~h}$, most of $A^{+}$WT-J and PBR-J cells were $\mathrm{Pl}^{+}$(Figure $2 \mathrm{a}$ ). These results indicate that early after UVB exposure (up to $4 \mathrm{~h}$ ), PBR-transfected cells were more resistant to apoptosis than WT-J cells suggesting that PBRs may exert a transient protective effect during the initial events of programmed cell death.

\section{Mitochondrial permeability transition after UVB exposure}

In a number of experimental systems, the early stage of the apoptotic process is characterized by the breakdown of the inner mitochondrial transmembrane potential $(\Delta \Psi \mathrm{m}){ }^{19}$ As $\mathrm{PBR}$ is part of the protein complex involved in the formation of mitochondrial permeability transition (PT) pores, ${ }^{8}$ we assessed the reduction of $\Delta \Psi \mathrm{m}$ that occurs after UVB exposure $\left(100 \mathrm{~mJ} / \mathrm{cm}^{2}\right)$ in WT and PBR-J cells. $\mathrm{DiOC}_{6}$ is a fluorochrome which incorporates into mitochondria in strict nonlinear dependence of $\Delta \Psi \mathrm{m}$ and emits exclusively within the spectrum of green light. One representative experiment is shown in Figure 3a. One hour after UVB, $41 \%$ of WT-J cells became $\mathrm{DiOC}_{6}{ }^{\text {low }} \mathrm{PI}^{-}$whereas $54 \%$ remained $\mathrm{PI}^{-} \mathrm{DiOC}_{6}{ }^{\text {high }}$.

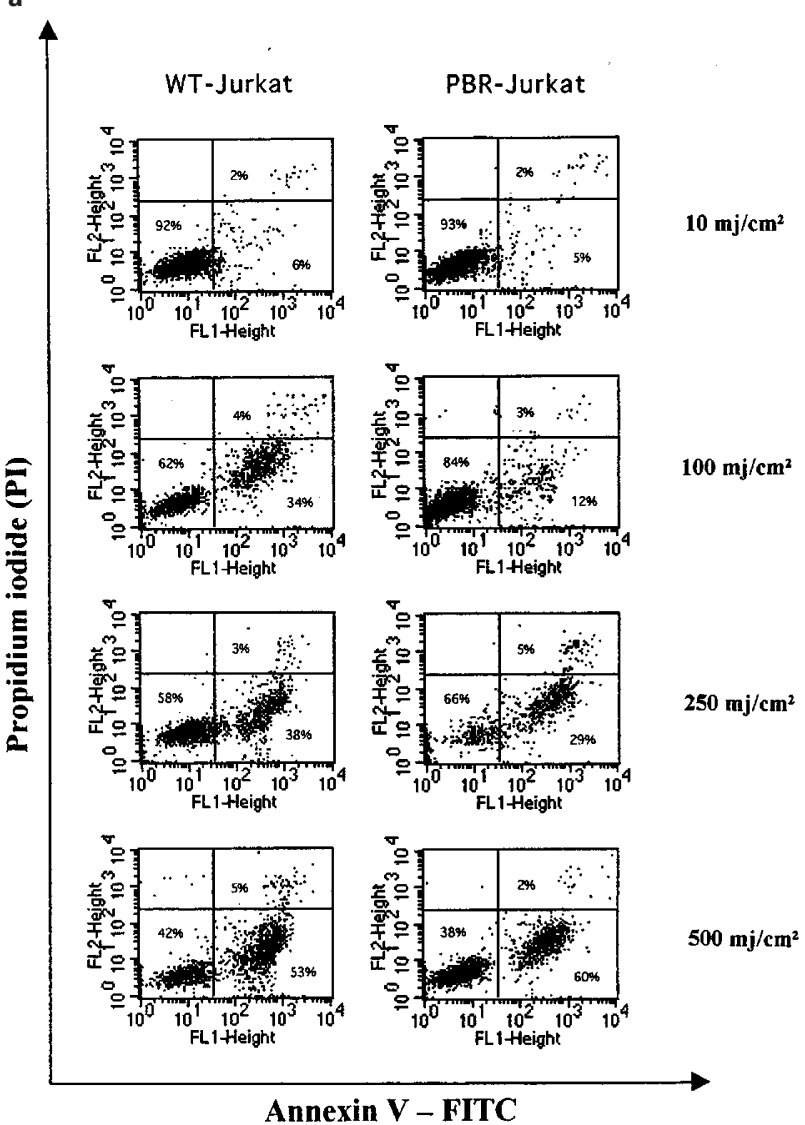

b

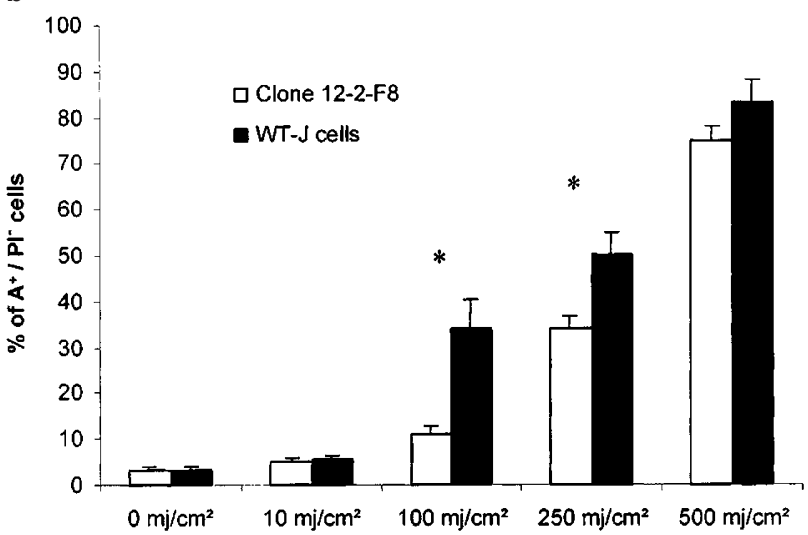

Figure 1 UVB-induced apoptosis in WT-J and PBR-J cell lines. Flow cytometric analysis of WT-J and PBR-J cells (12-2-F8 clone) labeled with Annexin V (FITC) and propidium iodide (PI) were performed at $1 \mathrm{~h}$ after increasing UVB doses $\left(10\right.$ to $500 \mathrm{~mJ} / \mathrm{cm}^{2}$ ). In both cell lines per cent of $\mathrm{API}^{+}$ cells (apoptotic cells) increased in a dose-dependent manner. There were significantly less apoptotic cells $(P=0.001)$ in PBR-J cells after $100 \mathrm{~mJ} / \mathrm{cm}^{2}$ and $250 \mathrm{~mJ} / \mathrm{cm}^{2}$ UVB exposures. The optimal difference between the apoptotic response of the two cell lines was obtained with a $100 \mathrm{~mJ} / \mathrm{cm}^{2}$ dose. Results are representative of three different determinations

By contrast the $\mathrm{DiOC}_{6}{ }^{\text {low }} \mathrm{PI}^{-}$cell subset was only $11 \%$ in PBR-J cells indicating that $1 \mathrm{~h}$ after UV, the release of $\mathrm{DiOC}_{6}$ was dramatically reduced in PBR-transfected cells. Until $4 \mathrm{~h}$ repeated experiments confirmed those results whereas at 12 
WT-Jurkat

PBR-Jurkat
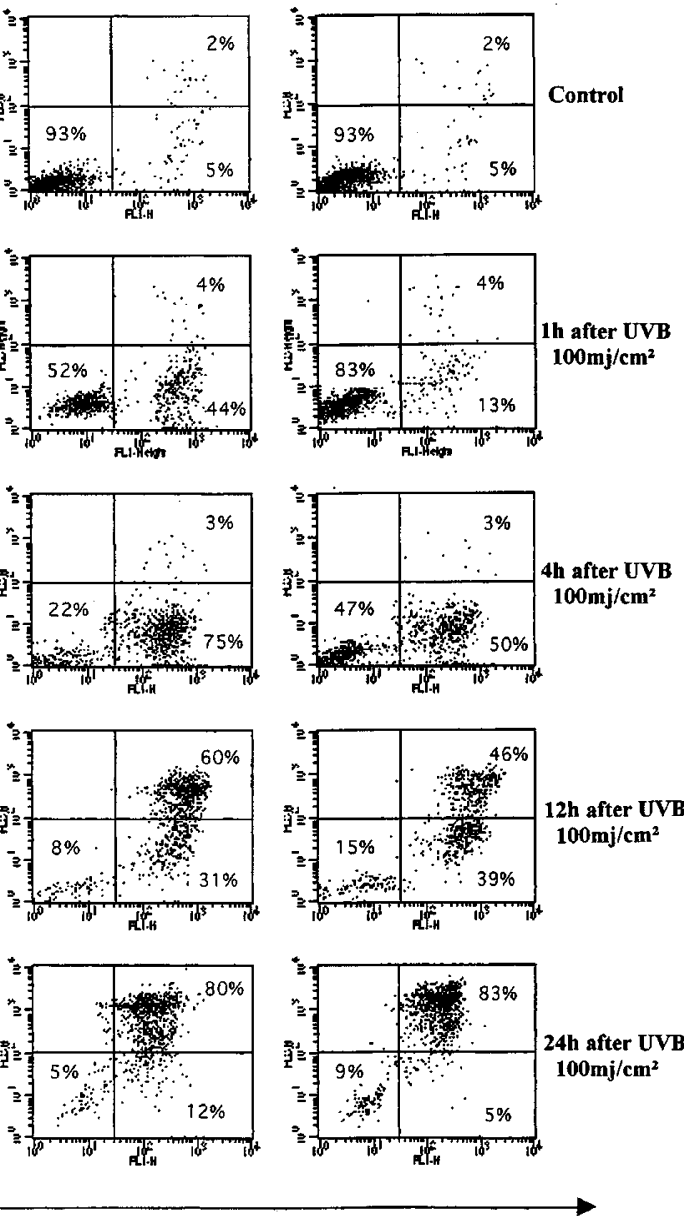

Annexin V - FITC

b

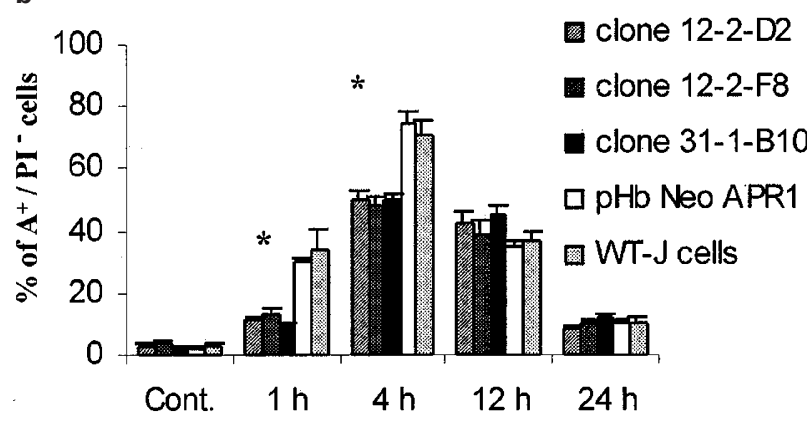

c

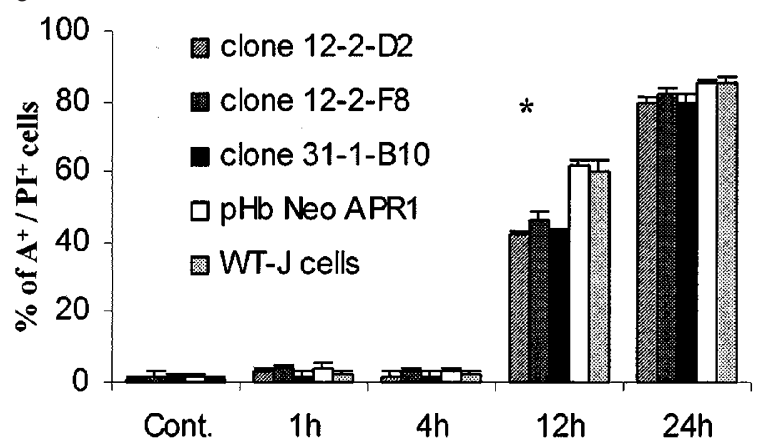

and $24 \mathrm{~h}$ no statistically significant difference could be observed between the two cell types (Figure 3b). Taken together these results indicate that shortly following UV exposure, the $\Delta \Psi \mathrm{m}$ drop is delayed in PBR-transfected cells compared to WT Jurkat cells.

\section{Superoxide anions production after UV exposure}

Reduction in $\Delta \Psi \mathrm{m}$ and subsequent reactive oxygen species (ROS) production are observed in several in vitro models of programmed cell death. Early events of apoptosis that occurred before the nucleus or nuclear DNA are fragmented, included first a fall in $\Delta \Psi \mathrm{m}$ followed by mitochondrial generation of ROS. ${ }^{20}$ To assess the production of superoxide anions, cells were labeled simultaneously with $\mathrm{DiOC}_{6}$ and oxidizing hydroethidine (HE), a substance that is oxidized by superoxide anions to produce ethidium and red fluorescence emission. ${ }^{21}$ A representative experiment is shown in Figure 4a. Flow cytometric analysis of WT and PBR-J cells (clone 122-F8) demonstrated that at each time point after UV exposure (1, 4 and $12 \mathrm{~h}$ ), only $\mathrm{DiOC}_{6}{ }^{\text {low }}$ cells produced superoxide anions. One hour after UV exposure, 44\% of WT-J cells displayed a reduced $\Delta \Psi \mathrm{m}\left(\mathrm{DiOC}_{6}{ }^{\text {low }}\right.$ population in the two left quadrants) and almost $50 \%$ of them $(21 \%$ of total number of cells) were Eth ${ }^{+}$. However, in PBR-J cells, only $8 \%$ of cells displayed a reduced $\Delta \Psi \mathrm{m}$ and one third (2\% of total cells) produced superoxide anions. Repeated experiments performed at 1, 4, 12 and $24 \mathrm{~h}$ (Figure $4 \mathrm{~b}$ ) indicate that until $4 \mathrm{~h}$ the superoxide anions production is significantly reduced in PBR-transfected cells $(P=0.001)$.

\section{Caspase-3 activation after UV exposure}

UV irradiation induces activation of caspase 3 (CPP32-like protease) in the early stages of apoptosis. ${ }^{22}$ As mitochondria plays a critical role in the initiation of the caspase cascade, ${ }^{23}$ we measured the activity of caspase-3 in WT-J and PBR-J cells at 1, 2, 4, 12 and $24 \mathrm{~h}$ after UVB exposure $\left(100 \mathrm{~mJ} / \mathrm{cm}^{2}\right)$. Shortly after irradiation, the activity of caspase-3 was increased in both WT and PBR-J cells up to $4 \mathrm{~h}$, and returned to its baseline level at $24 \mathrm{~h}$ (Figure 5). At 2 and $4 \mathrm{~h}$,

Figure 2 (a) UVB-induced apoptosis in WT-J and PBR-J cell lines. Flow cytometric analysis of WT-J and PBR-J cells (12-2-F8 clone) labeled with Annexin $\mathrm{V}$ (FITC) and propidium iodide (PI) were performed at 1, 4, 12 and $24 \mathrm{~h}$ after a UVB dose corresponding to $100 \mathrm{~mJ} / \mathrm{cm}^{2}$. Up to $4 \mathrm{~h}, \mathrm{~A}^{+} \mathrm{PI}^{-}$cellular subsets (lower right quadrants) are reduced in PBR-J cells. After $12 \mathrm{~h}$, per cent of $\mathrm{A}^{+} \mathrm{PI}^{-}$cells is greater in PBR-J cells (39\% vs $31 \%$ ) but $\mathrm{PI}^{+}$subset is still reduced compared to WT-J cells ( $46 \%$ vs $60 \%$ ). Results are representative of three independent experiments. Numbers refer to the percentage of cells contained in the indicated gate. (b) Kinetic study of apoptosis after UVB $\left(100 \mathrm{~mJ} / \mathrm{cm}^{2}\right)$ : at 1 and $4 \mathrm{~h}$, apoptotic $\mathrm{A}^{+} \mathrm{PI}^{-}$cellular subsets are significantly reduced in PBR-J cells $(P=0.001)$. Results are representative of three different determinations. No statistically significant difference was observed between 12-2-F8, 12-2-D2 and 31-1-B10 PBR transfected clones. The kinetic study was similar between Jurkat cells transfected with the corresponding empty vector ( $\mathrm{pHb}$ Neo APR1-J) and the WT-J cells. (c) Kinetic study of apoptosis after UVB $\left(100 \mathrm{~mJ} / \mathrm{cm}^{2}\right)$ : at $12 \mathrm{~h}$ non viable $\mathrm{A}^{+} \mathrm{PI}^{+}$cells are significantly reduced in PBR-J Jurkat cells $(P=0.001)$. No statistically significant difference was observed between 12-2-F8, 12-2-D2 and 31-1-B10 PBR transfected clones. The kinetic study was similar between WT-J and pHb Neo APR1-J cells. Results are representative of three different determinations 


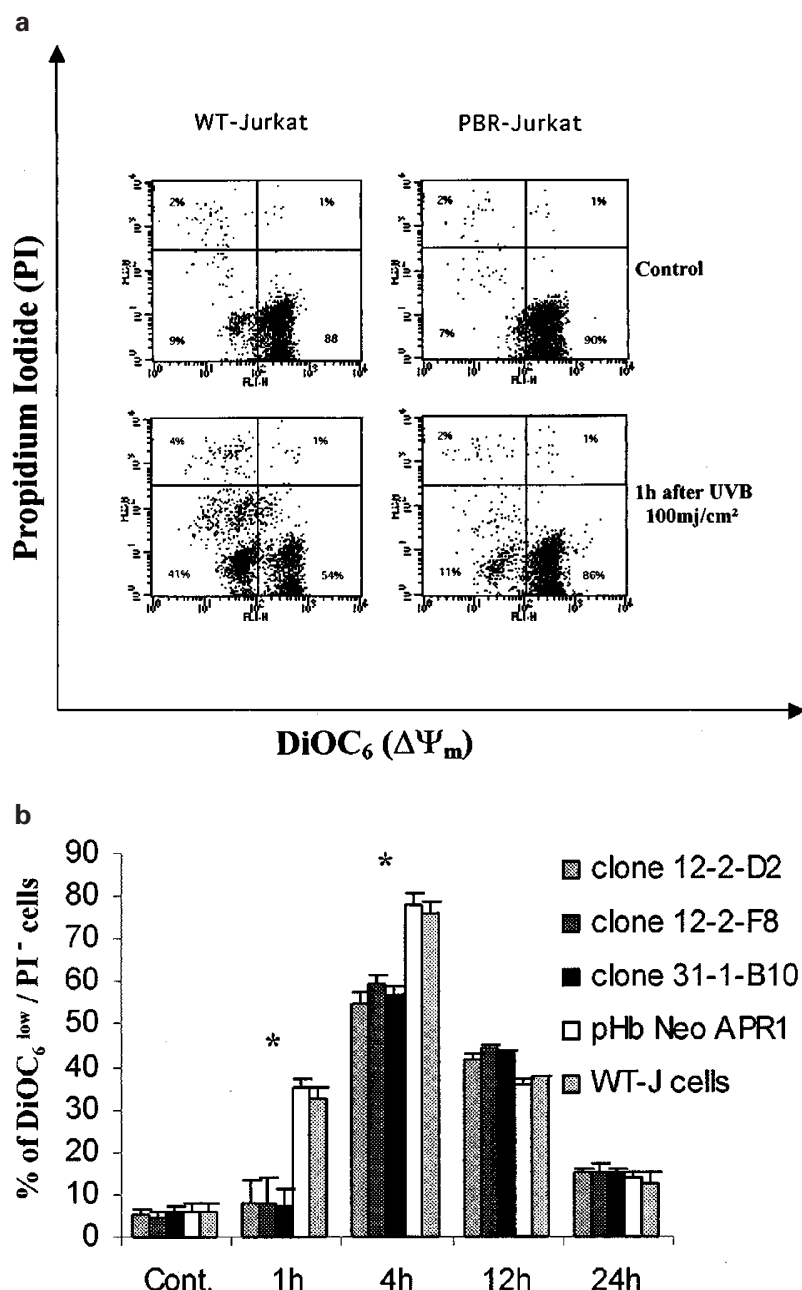

Figure 3 (a) UVB induced $\triangle \Psi m$ drop in WT-J and PBR-J cell lines. Flow cytometric analysis of WT-J and PBR-J cells (12-2-F8 clone) labeled with $\mathrm{DiOC}_{6} / \mathrm{PI} 1 \mathrm{~h}$ after UVB exposure. Regarding PI expression, cells can be separated into $\mathrm{PI}^{-}, \mathrm{Pl}^{+-}$and $\mathrm{PI}^{+}$populations. Gates were set on $\mathrm{Pl}^{+}$cells (upper left quadrants). After UVB, $41 \%$ of WT-J cells were DiOC6 ${ }_{\text {low }} \mathrm{PI}^{-}$ whereas only $11 \%$ of PBR-J cells dropped their $\Delta \Psi \mathrm{m}$ and became DiOC $6_{\text {low }}$ $\mathrm{PI}^{-}$. Results are representative of three independent experiments. (b) Kinetic study of $\Delta \Psi \mathrm{m}$ drop in WT-J and PBR-J cells after UVB irradiation. DiOC6 ${ }_{\text {low }} \mathrm{PI}^{-}$cellular subsets represent cells that have released $\mathrm{DiOC}_{6}$ and dropped their $\Delta \Psi \mathrm{m}$. At 1 and $4 \mathrm{~h}$ after UVB exposure $\left(100 \mathrm{~mJ} / \mathrm{cm}^{2}\right)$, there is a significant reduction of the DiOC6 ${ }_{\text {low }} \mathrm{PI}^{-}$subset in PBR-transfected Jurkat (PBR-J) cells $(P=0.001)$. At $12 \mathrm{~h}$, there is no statistically significant difference between the two types of cells. No statistically significant difference was observed between 12-2-F8, 12-2-D2 and 31-1-B10 PBR transfected clones. The kinetic study was similar between WT-J and pHb Neo APR1-J cells. Results are representative of three different experiments

caspase 3 activity was $20-50 \%$ higher in WT-J cells than that in PBR-J cells ( $P=0.01$, Wilcoxon test). These results indicate that PBR expression is linked to a downregulation of caspase3 activation that occurs in PBR-J cells shortly after UVB irradiation.

\section{Discussion}

Ultraviolet light (UV) generates singlet-oxygen damage and may trigger a PCD that does not require post-insult protein a

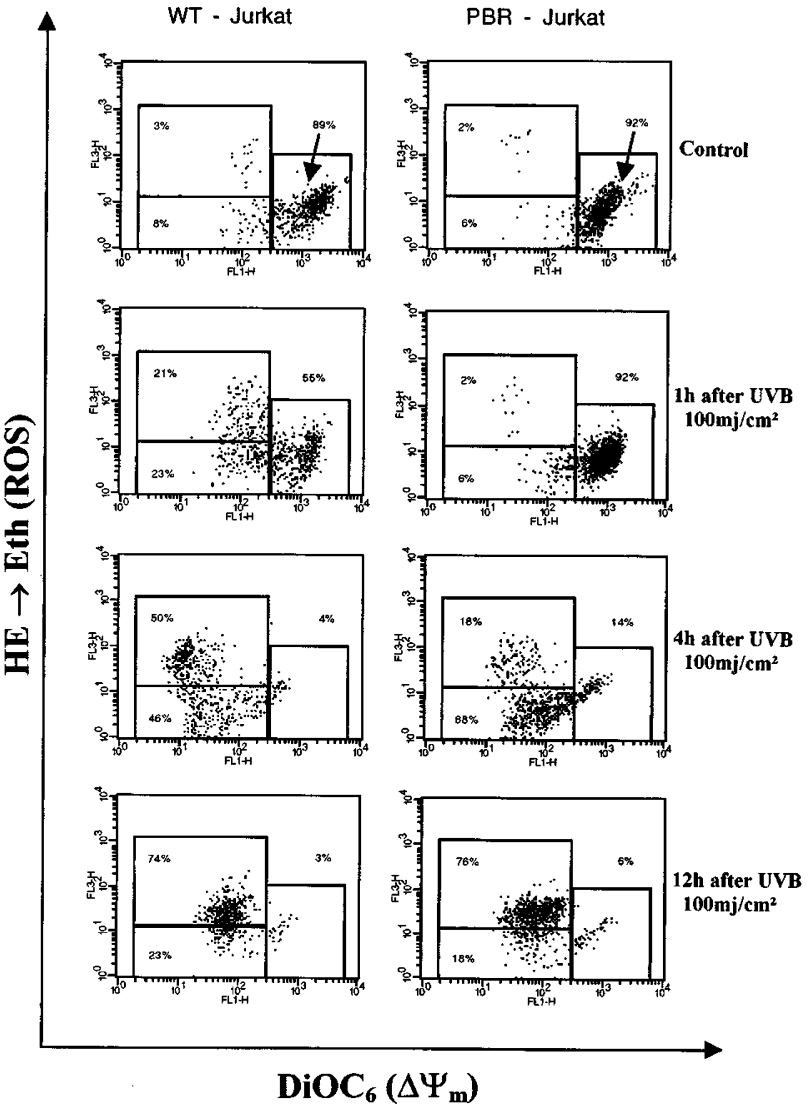

b

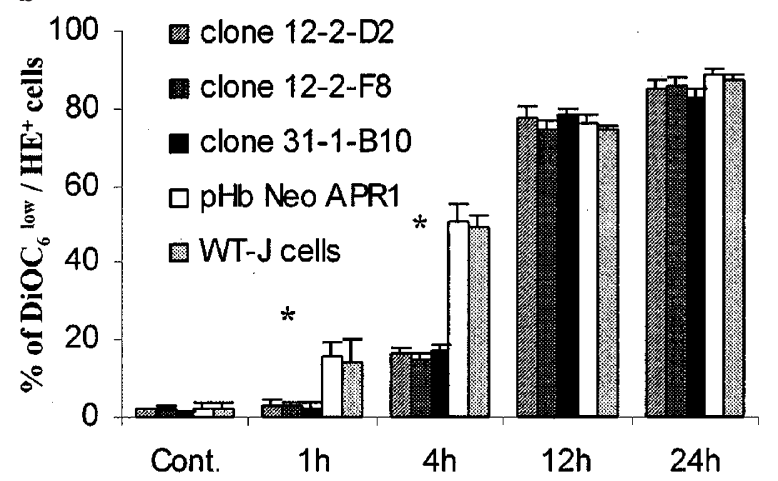

Figure 4 (a) UVB induced $\Delta \Psi \mathrm{m}$ drop and superoxide anions production in WT-J and PBR-J (12-2-F8 clone) cell lines. Flow cytometric analysis of WT-J and PBR-J cells were performed after UVB exposure. Cells were simultaneously stained with $\mathrm{DiOC}_{6}$ and $\mathrm{HE}$ (which allows for the determination of superoxide anion generation). Apoptotic DiOC6 ${ }_{\text {low }}$ Eth ${ }^{+}$ cellular subsets that produced ROS (upper left quadrants) are reduced in PBJ-J cells at 1 and $4 \mathrm{~h}$ after UV. Results are representative of three independent experiments. (b) Kinetic study of loss in $\Delta \Psi \mathrm{m}$ and superoxide anions production in WT-J and PBR-J cells after UVB irradiation. At 1 and $4 \mathrm{~h}$, superoxide anions production is significantly decreased in PBF-J cells $(P=0.001)$. No statistically significant difference was observed between $12-$ 2-F8, 12-2-D2 and 31-1-B10 PBR transfected clones. The kinetic study was similar between WT-J and pHb Neo APR1-J cells. Results are representative of three different determinations

synthesis. $^{24}$ This process may involve the PT pore which is a multiprotein complex formed at the contact site between the 


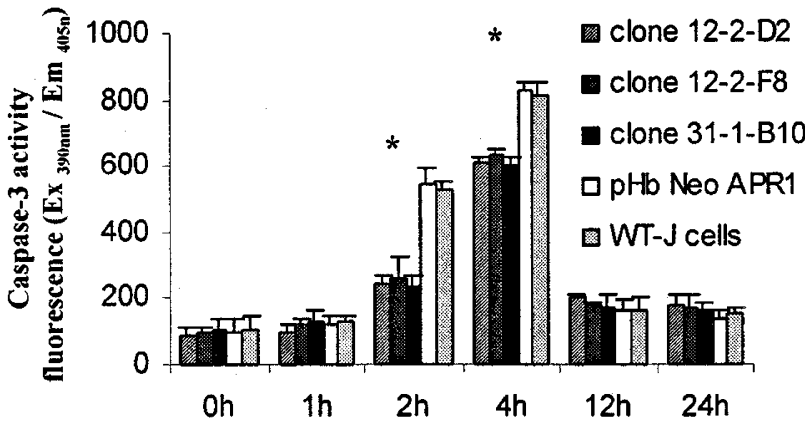

Figure 5 Kinetic study of caspase-3 activation after UVB exposure on PBR-J and WT-J cells. Jurkat cells were exposed to $100 \mathrm{~mJ} / \mathrm{cm}^{2}$ UVB and incubated for $24 \mathrm{~h}$ at $37^{\circ} \mathrm{C}$. Lysates were analyzed for caspase-3 activity and fluorescence (minus fluorescence of background) was plotted versus time. Caspase- 3 activity is significantly decreased in PBR-J cells at 2 and $4 \mathrm{~h}$ $(P=0.01)$. No statistically significant difference was observed between 12-2F8, 12-2-D2 and 31-1-B10 PBR transfected clones. The kinetic study was similar between WT-J and pHb Neo APR1-J cells. Results are representative of three independent experiments

mitochondrial inner and outer membranes. The exact molecular composition of the pore is still unknown although several proteins have been described involved in mitochondrial PT pore formation such as VDAC (mitochondrial porine), ANT and PBR. ${ }^{8}$ Opening the PT pore can cause the dissipation of the inner mitochondrial transmembrane potential $(\Delta \Psi \mathrm{m})$ that is a critical event in the process leading to apoptosis. ${ }^{12,25,26}$ Moreover, recent evidence suggests that PT pore complex (PTPC) may constitute a crossroad of apoptosis regulation by caspases and members of the $\mathrm{Bcl}-2$ family. ${ }^{19,27}$ Indeed, Bcl-2 proteins are particularly abundant in mitochondrial membrane where they are closely associated to PBRs and other proteins of the PTPC. ${ }^{10}$ Recent data demonstrate that proteins of the $\mathrm{Bcl} 2$ family bind to VDAC and regulate the mitochondrial membrane potential and the release of cytochrome $c$ during apoptosis. ${ }^{11}$ Thus, a functional interaction between $\mathrm{Bcl}-2$ and other components of PTPC such as PBR cannot be excluded. Interestingly, PK11195, a specific antagonistic ligand of PBR, facilitates the induction of apoptosis by triggering $\Delta \Psi \mathrm{m}$ disruption and reverses $\mathrm{Bcl}-2$ mediated cytoprotection. ${ }^{15,28}$ Moreover, $\mathrm{Bcl}-2$ protects isolated mitochondria against the opening of the PT pore induced by low doses of protoporphyrin IX, a ligand of PBR. ${ }^{29}$ Mechanisms by which PBR and Bcl-2 exert anti-apoptotic effects are still not known and require further studies. Recent data demonstrate that a PBR agonistic ligand (Ro5-4864) is a potent anti-apoptotic compound. ${ }^{16}$ Finally the results reported here indicate that transfection-induced hyperexpression of the PBR gene protects against early UV-induced apoptosis as evidenced by a delay in mitochondrial changes and suggest that $\Delta \Psi \mathrm{m}$ is stabilized by PBR. Altogether these data suggest a critical role for PBR in the apoptotic process.

Reactive oxygen species (ROS) are involved in many forms of PCD and in several in vitro models reduction of $\Delta \Psi \mathrm{m}$ is followed by enhanced production of ROS and subsequent DNA fragmentation and nuclear DNA loss. ${ }^{20,30}$ UV-induced oxidative DNA damage is rapidly followed by the loss of $\Delta \Psi \mathrm{m}$ and the activation of caspase-3, resulting in apoptosis. ${ }^{31}$ The demonstration of the role of PBR in the protection of hematopoietic cells against $\mathrm{H}_{2} \mathrm{O}_{2}$ suggests that PBR may prevent mitochondria from radical damage. $^{14}$ Our findings are in agreement with these results and argue that PBR may be involved in ROS production induced by UV light. Mechanisms underlying these effects are still unclear but one may hypothesize that the reduced fall in $\Delta \Psi \mathrm{m}$ due to PBR transfection results in a decreased generation of ROS that occurs shortly after UVB exposure. Indeed, PT pores participate in the generation of matrix $\mathrm{Ca}^{2+}, \mathrm{pH}, \Delta \Psi \mathrm{m}$ and redox-gated channel, and is implicated in cell death induced by anoxia, ROS, and calcium overload. ${ }^{27}$ Furthermore, opening the PT pores leads to the release of cytochrome $c$ from mitochondria to the cytosol, thereby triggering caspases activation and cell death by apoptosis. ${ }^{32-35}$ Indeed, mitochondria are involved in the initiation of the caspase activation by releasing cytochrome $c$ into the cytosol where it binds to the adaptator molecule Apaf-1 (apoptotic protease activating factor 1$).^{35}$ This complex activates caspase- 9 which then cleaves and activates downstream caspases such as caspase-3, -6 , and -7 . This pathway is regulated at several steps and caspase substrates such as $\mathrm{Bcl}-2$ proteins appear to promote further caspase activation as part of a positive feedback loop. ${ }^{36}$ Caspase-3 is a frequently activated death protease, catalyzing the specific cleavage of many key cellular proteins ${ }^{37}$ and initiating apoptotic DNA fragmentation. ${ }^{38}$ Recent data demonstrate that activation of caspase- 3 is increased in the early stages of UVB-induced apoptosis. ${ }^{22,39}$ Our results indicate that caspase-3 activation after UVB is delayed in PBRtransfected cells. Whether this effect is related to proteinprotein interactions within the mitochondrial PT pore or results from a disruption of the feedback loop control of caspase activation remains to be elucidated. ${ }^{33,40}$ Nevertheless, our results indicate that PBR, an important component of mitochondrial PT pore, may exert transient anti-apoptotic effects during the early events of UV-induced $P C D$. These findings are in agreement with pharmacological studies showing that PBR ligands may modulate apoptosis $^{15,16,28}$ of hematopoietic cells as well as epithelial or hematological malignancies. ${ }^{41}$ Taken together, these observations provide compelling evidence indicating that PBR belongs to the protein family which may interact within the mitochondrial membrane to regulate death signals leading to apoptosis.

\section{Materials and Methods}

\section{Materials}

Stable transfectants PBJ-J (12-2-F8, 31-1-B10 and 12-2-D2 clones) and the corresponding WT-J cell lines and empty-vector transfected Jurkat cell lines ( $\mathrm{pHb}$ Neo APR1-J) were kindly provided by SanofiSynthelabo (Montpellier, France). ${ }^{14}$ Quantitation of the number of PBR sites per cell was performed by flow cytometry using no conjugated anti-PBR MoAb and the QIFI assay (QIFIKIT; Dako). ${ }^{18}$ Clones 12-2-F8, 31-B-10 and 12-2-D2 expressed $90000 \pm 10000$, $50000 \pm 10000$ and $45000 \pm 5000$ PBR sites per cell respectively. WT-J and $\mathrm{pHb}$ Neo APR1-J cells were devoid of any PBR 
expression. ${ }^{14}$ RPMI 1640 medium, phosphate-buffered saline (PBS), pyruvic acid, and essential and nonessential amino acids solutions were obtained from Gibco BRL (Cergy-pontoise, France). Fetal calf serum (FCS), penicillin, streptomycin sulfate and glutamine were purchased at Boehringer Mannheim (Meylan, Claix, France).

\section{Cell cultures and UVB irradiation}

WT-J and PBJ-J cell lines were routinely cultured in RPMI 1640 culture medium supplemented with $10 \%$ heat-inactivated FCS, $4 \mathrm{mM}$ glutamine, $50 \mathrm{U} / \mathrm{ml}$ penicillin and $50 \mu \mathrm{g} / \mathrm{ml}$ streptomycin sulfate at $37^{\circ} \mathrm{C}$ under $5 \% \mathrm{CO}_{2}$ in a humidified atmosphere. WT-J and PBJ-J cells were seeded in $35 \mathrm{~mm}$ Petri dishes $\left(10^{6}\right.$ cells/well) in phenol red-free RPMI 1640 containing $10 \%$ FCS. Cells were exposed to UVB radiation $\left(290-320 \mathrm{~nm}\right.$, doses ranged from 0 to $\left.500 \mathrm{~mJ} / \mathrm{cm}^{2}\right)$ by using a UV 800 Waldman device (Reichstett, France). Power density was monitored before each experiment by using a Waldmann UV-Meter (Waldmann, Schwenningen, Germany). The source to target distance was $30 \mathrm{~cm}$ and the cell culture temperature was kept constant at $25^{\circ} \mathrm{C}$ during irradiation. Sham-irradiated samples were used as controls. After irradiation, the cells were incubated at standard culture conditions for the given time periods.

\section{Flow cytometric detection of apoptosis}

The UVB induced cell death was analyzed at 1, 4, 12, $24 \mathrm{~h}$ after irradiation using flow cytometric detection of phosphatidylserine expression with the Annexin V-FITC kit (Bender MedSystems, Vienna, Austria). Briefly, cells $\left(5 \times 10^{5}\right.$ cells) were washed twice in PBS and resuspended in $195 \mu$ l binding buffer (10 mM HEPES/NaOH $\mathrm{pH} 7.4,140 \mathrm{mM} \mathrm{NaCl}, 2.5 \mathrm{mM} \mathrm{CaCl}_{2}$ ) and then incubated for $10 \mathrm{~min}$ at room temperature with $5 \mu \mathrm{l}$ annexinV-FITC. After wash, cells were resuspended in $190 \mu \mathrm{l}$ binding buffer and Propidium lodide were added to a final concentration of $1 \mu \mathrm{g} / \mathrm{ml}$ for flow cytometric analysis. Bivariate analysis was performed on a FACSCan (Becton Dickinson, Mountain View, USA) equipped with a $488 \mathrm{~nm}$ argon laser. A minimum of 10000 cells per sample was recorded and stored in list mode files. Data analysis was performed using the CELLQuest software (Becton Dickinson, St. Louis, USA).

\section{Cytofluorometric analysis of mitochondrial transmembrane potential $(\Delta \Psi \mathrm{m})$, and superoxide anions generation}

After UVB irradiation, cells were incubated from 0 to $24 \mathrm{~h}$ at $37^{\circ} \mathrm{C}$ in the standard medium. Following published protocols ${ }^{19,20}$ the following fluorochromes were employed to determine different apoptosisassociated change: to assess $\Delta \Psi \mathrm{m}$ and cell mortality, cells $\left(5 \times 10^{5}\right.$ cells $/ \mathrm{ml}$ ) were washed twice and incubated with 3,3'-dihexyloxacarbocyanine iodide $\left(\mathrm{DiOC}_{6}\right), 40 \mathrm{nM}$ in PBS; Molecular Probes Inc., Eugene, OR, USA) and propidium iodide (PI, $5 \mu \mathrm{g} / \mathrm{ml})$. To measure $\Delta \Psi \mathrm{m}$ and superoxide anions generation, cells $\left(5 \times 10^{5}\right.$ cells $\left./ \mathrm{ml}\right)$ were washed twice and incubated with $\mathrm{DiOC}_{6}$ and dihydroethidine $(\mathrm{HE}$; $2 \mu \mathrm{M}$, Molecular Probes Inc., Eugene, OR, USA) for $15 \mathrm{~min}$ at room temperature. After incubation, cells were washed and suspended in PBS, and then analyzed on a FACScan.

\section{Measurement of caspase- 3 activity}

After a $100 \mathrm{~mJ} / \mathrm{cm}^{2}$ UVB irradiation, cells were continuously incubated at $37^{\circ} \mathrm{C}$ for $1,2,4,12$ and $24 \mathrm{~h}$ in the standard medium. Caspase-3 activity was determined using a Fluorometric Immunosorbent Enzyme Assay kit (Boehringer Mannheim, Germany) according to the manufacturer's instructions. Briefly, cells $\left(2 \times 10^{6}\right.$ cells) were washed with ice cold PBS and suspended in $200 \mu \mathrm{l}$ of lysis buffer for $1 \mathrm{~min}$ on ice. Cell lysates were centrifugated at $1800 \times g$ for $15 \mathrm{mn}$ and supernatants were collected. The reaction was initiated by addition of Ac-DEVD-AFC (Z-Asp-Glu-Val-Asp-7amino-4-trifluoromethyl coumarin) to anti-caspase 3-coated microtiter containing apoptotic extract. Product formation was measured by using a Hitachi F-2000 spectrofluorometer with excitation at $400 \mathrm{~nm}$ and emission at $505 \mathrm{~nm}$.

\section{References}

1. Braestrup C and Squires RF (1977) Specific benzodiazepine receptors in rat brain characterized by high-affinity $(3 \mathrm{H})$ diazepam binding. Proc. Natl. Acad. Sci. USA 74: 3805-3809

2. Anholt RRH, Pedersen PL, De Souza EB and Snyder SH (1986) The peripheraltype benzodiazepine receptor. Localization to the mitochondrial outer membrane. J. Biol. Chem. 261: 576-583

3. Verna A, Nye J and SnyderSH (1987) Porphyrins are endogenous ligands for the mitochondrial (peripheral-type) benzodiazepine receptor. Proc. Natl. Acad. Sci. USA 84: 2256-2260

4. Galiegue S, Jbilo O, Combes T, Bribes E, Carayon P, Le Fur G and Casellas P (1999) Cloning and characterization of PRAX-1. A new protein that specifically interacts with the peripheral benzodiazepine receptor. J. Biol. Chem. 274: 2938-2952

5. Krueger KE (1995) Molecular and functional properties of mitochondrial benzodiazepine receptors. Biochim. Biophys. Acta 1241: 453-470

6. Yeliseev AA, Krueger KE and Kaplan S (1997) A mammalian mitochondrial drug receptor functions as a bacterial 'oxygen' sensor. Proc. Natl. Acad. Sci. USA 94: $5101-5106$

7. Yeliseev AA and Kaplan S (2000) TspO of rhodobacter sphaeroides. A structural and functional model for the mammalian peripheral benzodiazepine receptor. J. Biol. Chem. 275: 5657-5667

8. McEnery MW, Snowman AM, Trifiletti RR and Snyder SH (1992) Isolation of the mitochondrial benzodiazepine receptor: association with voltage-dependent anion channel and the adenine nucleotide carrier. Proc. Natl. Acad. Sci. USA 89: 3170-3174

9. Zamzami N, Marchetti P, Castedo M, Zanin C, Vayssiere J, Petit PX and Kroemer $G$ (1995) Reduction in mitochondrial potential constitutes an early irreversible step of programmed lymphocyte death in vivo. J. Exp. Med. 181: 1661-1672

10. Kroemer $\mathrm{G}$ (1997) The proto-oncogene Bcl-2 and its role in regulating apoptosis. Nat. Med. 3: 614-620

11. Shimizu S, Narita M and Tsujimoto Y (1999) Bcl-2 family proteins regulate the release of apoptogenic cytochrome $c$ by the mitochondrial channel VDAC. Nature 399: 483-487

12. Kroemer G, Zamzami N and Susin SA (1997) Mitochondrial control of apoptosis. Immunol. Today 18: 44-51

13. Bauer MK, Schubert A, Rocks O and Grimm S (1999) Adenine nucleotide translocase-1, a component of the permeability transition pore, can dominantly induce apoptosis. J. Cell. Biol. 147: 1493-1502

14. Carayon P, Portier M, Dussossoy D, Bord A, Petitpretre G, Canat X, Le Fur G and Casellas P (1996) Involvement of peripheral bnezodiazepine receptors in the protection of hematopoietic cells against oxygen radical damage. Blood 87: $3170-3178$

15. Hirsch T, Decaudin D, Susin SA, Marchetti P, Larochette N, Resche-Rigon Mand Kroemer G (1998) PK11195, a ligand of the mitochondrial benzodiazepine receptor, facilitates the induction of apoptosis and reverses Bcl-2-mediated cytoprotection. Exp. Cell Res. 241: 426-434

16. Bono F, Lamarche I, Prabonnaud V, Le Fur G and Herbert JM (1999) Peripheral benzodiazepine receptor agonists exhibit potent antiapoptotic activities. Biochem. Biophys. Res. Commun. 265: 457-461

17. Stoebner PE, Carayon P, Penarier G, Frechin N, Barneon G, Casellas P, Cano $J P$, Meynadier $J$ and Meunier L (1999) The expression of peripheral benzodiazepine receptors in human skin: the relationship with epidermal cell differentiation. Br. J. Dermatol. 140: 1010-1016 
18. Dussossoy D, Carayon P, Feraut D, Belugou S, Combes T, Canat X, Vidal H and Casellas P (1996) Development of a monoclonal antibody to immunocytochemical analysis of the cellular localization of the peripheral benzodiazepine receptor. Cytometry 24: $39-48$

19. Marchetti P, Castedo M, Susin SA, Zamzami N, Hirsch T, Macho A, Haeffner A, Hirsch F, Geuskens M and Kroemer G (1996) Mitochondrial permeability transition is a central coordinating event of apoptosis. J. Exp. Med. 184: 11551160

20. Zamzami N, Marchetti P, Castedo M, Decaudin D, Macho A, Hirsch T, Susin SA, PetitPX, Mignotte B and Kroemer G(1995) Sequential reduction of mitochondrial transmembrane potential and generation of reactive oxygen species in early programmed cell death. J. Exp. Med. 182: 367-377

21. Rothe $G$ and Valet $G$ (1990) Flow cytometric analysis of respiratory burst activity in phagocytes with hydroethidine and 2',7'-dichlorofluorescin. J. Leukoc. Biol. 47: $440-448$

22. Shimizu H, Banno Y, Sumi N, Naganawa T, Kitajima $Y$ and Nozawa $Y$ (1999) Activation of p38 mitogen-activated protein kinase and caspases in UVBinduced apoptosis of human keratinocyte HaCat cells. J. Invest. Dermatol. 112: $769-774$

23. Wolf BB and Green DR (1999) Suicidal tendencies: apoptotic cell death by caspase family proteinases. J. Biol. Chem. 274: 20049-20052

24. Godar DE (1999) Light and death: photons and apoptosis. J. Investig. Dermatol. Symp. Proc. 4: 17-23

25. Zamzami N, Susin SA, Marchetti P, Hirsch T, Gomez-Monterrey I, Castedo Mand Kroemer G (1996) Mitochondrial control of nuclear apoptosis. J. Exp. Med. 183: 1533- 1544

26. Green DR and Reed JC (1998) Mitochondria and apoptosis. Science 281: 1309-1312

27. Marzo I, Brenner C, Zamzami N, Susin SA, Beutner G, Brdiczka D, Remy R, Xie ZH, Reed JC and Kroemer G (1998) The permeability transition pore complex: a target for apoptosis regulation by caspases and bcl-2-related proteins. J. Exp. Med. 187: 1261-1271

28. Tanimoto Y, Onishi Y, Sato Y and Kizaki H (1999) Benzodiazepine receptor agonists modulate thymocyte apoptosis through reduction of the mitochondrial transmembrane potential. Jpn. J. Pharmacol. 79: 177-183

29. Marchetti P, Hirsch T, Zamzami N, Castedo M, Decaudin D, Susin SA, Massa B and Kroemer $G$ (1996) Mitochondrial permeability transition triggers lymphocyte apoptosis. J. Immunol. 157: 4830-4836

30. Tan S, Sagara Y, LiuY, Maher P and SchubertD (1998) The regulation of reactive oxygen species production during programmed cell death. J. Cell. Biol. 141: 1423-1432
31. Tada-Oikawa S, Oikawa S and Kawanishi S (1998) Role of ultraviolet A-induced oxidative DNA damage in apoptosis via loss of mitochondrial membrane potential and caspase-3 activation. Biochem. Biophys. Res. Commun. 247: 693-696

32. Goldstein JC, Waterhouse NJ, Juin P, Evan GI and Green DR (2000) The coordinate release of cytochrome $c$ during apoptosis is rapid, complete and kinetically invariant. Nat. Cell Biol. 2: 156-162

33. Chen Q, Gong B and Almasan A (2000) Distinct stages of cytochrome c release from mitochondria: evidence for a feedback amplification loop linking caspase activation to mitochondrial dysfunction in genotoxic stress induced apoptosis. Cell Death Differ. 7: 227-233

34. Daugas E, Susin SA, Zamzami N, Ferri KF, Irinopoulou T, Larochette N, Prevost MC, Leber B, Andrews D, Penninger J and Kroemer G (2000) Mitochondrionuclear translocation of AIF in apoptosis and necrosis. FASEB J. 14: 729-739

35. Bossy-Wetzel E and Green DR (1999) Caspases induce cytochrome c release from mitochondria by activating cytosolic factors. J. Biol. Chem. 274: 17484 17490

36. Kirsch DG, Doseff A, Chau BN, Lim DS, de Souza-Pinto NC, Hansford R, Kastan MB, Lazebnik YA and Hardwick JM (1999) Caspase-3-dependent cleavage of Bcl-2 promotes release of cytochrome c. J. Biol. Chem. 274:21155-21161

37. Porter AG and Janicke RU (1999) Emerging roles of caspase-3 in apoptosis. Cell Death Differ. 6: 99-104

38. Wolf BB, Schuler M, Echeverri F and Green DR (1999) Caspase-3 is the primary activator of apoptotic DNA fragmentation via DNA fragmentation factor-45/ inhibitor of caspase-activated DNase inactivation. J. Biol. Chem. 274: 30651 30656

39. Aragane Y, Kulms D, Metze D, Wilkes G, Poppelmann B. Luger TA and Schwarz T (1998) Ultraviolet light induces apoptosis via direct activation of CD95 (Fas/ APO-1) independently of its ligand CD95L. J. Cell. Biol. 140: 171-182

40. Slee EA, Keogh SA and Martin SJ (2000) Cleavage of BID during cytotoxic drug and UV radiation-induced apoptosis occurs downstream of the point of Bcl-2 action and is catalysed by caspase-3: a potential feedback loop for amplification of apoptosis-associated mitochondrial cytochrome c release. Cell Death Differ 7: $556-565$

41. Xia W, Spector S, Hardy L, Zhao S, Saluk A, Alemane L and Spector NL (2000) Tumor selective G2/M cell cycle arrest and apoptosis of epithelial and hematological malignancies by BBL22, a benzazepine. Proc. Natl. Acad. Sci. USA 97: 7494-7499 